\title{
Roadmap for the development of alternative test methods
}

\author{
Tim Brecklinghaus $^{1}$ (D)
}

Received: 17 August 2020 / Accepted: 18 August 2020 / Published online: 28 August 2020

(c) The Author(s) 2020

Recently, a roadmap on how to develop in vitro and in silico alternative methods to animal experiments has been published (Sachinidis et al. 2019). The authors suggest a strategy with five milestones:

- Testing of gold standard compounds and pathway controls (Sachinidis et al. 2019; Hengstler et al. 2014). Gold standard compounds are substances for which human toxicity is well understood. Moreover, it should be well established at which concentration ranges a gold standard control should lead to positive and negative results. For example, acetaminophen (APAP) should lead to positive test results at concentrations of 1-2 mM, while concentrations below $0.1 \mathrm{mM}$ should test negative in test methods for hepatotoxicity (Godoy et al. 2013). Pathway controls specifically interfere with specific signal transduction mechanisms. For example, Wnt inhibitors should cause positive test results in test systems of developmental toxicity. Many novel test methods fail already when challenged with gold standard compounds and pathway controls.

- Establishment of test performance metrics. This step requires about 20 positive and negative test compounds of which the blood concentration, e.g., the $\mathrm{C}_{\max }$ resulting from a specific dosing schedule is known. Moreover, knowledge is required on whether this dosing schedule causes toxicity (positive control) or not (negative control) to a specific organ (e.g., liver or kidney). Based on the lowest positively tested in vitro concentration, two performance indices can be calculated: the toxicity separation index (TSI) informs how well a test system differentiates between toxic and non-toxic compounds; the toxicity estimation index (TEI) is a measure of how

Tim Brecklinghaus

brecklinghaus@ifado.de

1 Leibniz Research Centre for Working Environment and Human Factors, Ardeystr 67, 44139 Dortmund, Germany well the in vitro test estimates toxic blood concentrations (only for positive controls).

- Iterative cycles of optimization and confirmation. Many test parameters require optimization. A typical example is the exposure period with test compounds. Often the question arises, whether inclusion of an additional readout into the test battery improves performance. This can be objectified by the above-introduced performance metrics TSI and TEI. However, it is important to confirm improvements for independent sets of positive and negative controls to avoid overfitting to a single set of data.

- Evaluation of inter-laboratory reproducibility. This step requires testing of the same compounds by independent laboratories to determine inter-laboratory reproducibility.

- Acceptance by the scientific community and regulatory bodies. Often regulatory bodies have been asked for acceptance of test methods that are by far not sufficiently advanced. Data of at least 300 positive and negative control compounds should be available and conventional performance measures such as sensitivity or specificity should have been determined by independent laboratories.

In recent years, numerous in vitro tests have been developed, particularly for nephrotoxicity (Lee et al. 2017; Jiang et al. 2018; Sjögren et al. 2018), neurotoxicity (Colaianna et al. 2017; Sisnaike et al. 2014; Reffatto et al. 2018; Yang et al. 2018; Keil et al. 2018), developmental toxicity (Adam et al. 2019; Krug et al. 2013; Shinde et al. 2017; Rempel et al. 2015; Waldmann et al. 2014) and hepatotoxicity (Godoy et al. 2013, 2015; Grinberg et al. 2014, 2018; Reif et al. 2015; Leist et al. 2017), often supported by methods of systems modeling (Hoehme et al. 2010; Ghallab et al. 2016; Vartak et al. 2016; Jansen et al. 2017). However, relatively little has been done to quantitatively evaluate how well in vitro/in silico methods resemble the in vivo situation. For this purpose, the road map presented by Sachinidis and colleagues represents a helpful and practical guideline. 
Acknowledgements Open Access funding provided by Projekt DEAL.

\section{Compliance with ethical standards}

Conflict of interest The author declares that he has no conflict of interest.

Open Access This article is licensed under a Creative Commons Attribution 4.0 International License, which permits use, sharing, adaptation, distribution and reproduction in any medium or format, as long as you give appropriate credit to the original author(s) and the source, provide a link to the Creative Commons licence, and indicate if changes were made. The images or other third party material in this article are included in the article's Creative Commons licence, unless indicated otherwise in a credit line to the material. If material is not included in the article's Creative Commons licence and your intended use is not permitted by statutory regulation or exceeds the permitted use, you will need to obtain permission directly from the copyright holder. To view a copy of this licence, visit http://creativecommons.org/licenses/by/4.0/.

\section{References}

Adam AHB, Zhang M, de Haan LHJ et al (2019) The in vivo developmental toxicity of diethylstilbestrol (DES) in rat evaluated by an alternative testing strategy. Arch Toxicol. https://doi.org/10.1007/ s00204-019-02487-6

Colaianna M, Ilmjärv S, Peterson H, Kern I et al (2017) Fingerprinting of neurotoxic compounds using a mouse embryonic stem cell dual luminescence reporter assay. Arch Toxicol 91(1):365-391

Ghallab A, Cellière G, Henkel SG et al (2016) Model-guided identification of a therapeutic strategy to reduce hyperammonemia in liver diseases. J Hepatol 64(4):860-871. https://doi.org/10.1016/j. jhep.2015.11.018

Godoy P, Hewitt NJ, Albrecht U et al (2013) Recent advances in 2D and $3 \mathrm{D}$ in vitro systems using primary hepatocytes, alternative hepatocyte sources and non-parenchymal liver cells and their use in investigating mechanisms of hepatotoxicity, cell signaling and ADME. Arch Toxicol 87(8):1315-1530. https://doi.org/10.1007/ s00204-013-1078-5 (Review)

Godoy P, Schmidt-Heck W, Natarajan K et al (2015) Gene networks and transcription factor motifs defining the differentiation of stem cells into hepatocyte-like cells. J Hepatol 63(4):934-942. https:// doi.org/10.1016/j.jhep.2015.05.013 (Erratum.In:J Hepatol 2016 Feb; 64(2): 525-6)

Grinberg M, Stöber RM, Edlund K et al (2014) Toxicogenomics directory of chemically exposed human hepatocytes. Arch Toxicol 88(12):2261-2287. https://doi.org/10.1007/s00204-014-1400-x

Grinberg M, Stöber RM, Albrecht W et al (2018) Toxicogenomics directory of rat hepatotoxicants in vivo and in cultivated hepatocytes. Arch Toxicol 92(12):3517-3533. https://doi.org/10.1007/ s00204-018-2352-3

Hengstler JG, Marchan R, Bolt HM (2014) Fingerprinting of neurotoxic compounds using a mouse embryonic stem cell dual luminescence reporter assay. Arch Toxicol 88(12):2083-2084. https ://doi.org/10.1007/s00204-014-1398-0 (No abstract available)

Hoehme S, Brulport M, Bauer A et al (2010) Prediction and validation of cell alignment along microvessels as order principle to restore tissue architecture in liver regeneration. Proc Natl Acad Sci USA 107(23):10371-10376

Jansen PL, Ghallab A, Vartak N et al (2017) The ascending pathophysiology of cholestatic liver disease. Hepatology 65(2):722-738. https://doi.org/10.1002/hep.28965 (Review)
Jiang S, Lin Y, Yao H et al (2018) The role of unfolded protein response and ER-phagy in quantum dots-induced nephrotoxicity: an in vitro and in vivo study. Arch Toxicol 92(4):1421-1434. https ://doi.org/10.1007/s00204-018-2169-0

Keil KP, Miller GW, Chen H (2018) PCB 95 promotes dendritic growth in primary rat hippocampal neurons via mTOR-dependent mechanisms. Arch oxicol 92(10):3163-3173

Krug AK, Kolde R, Gaspar JA et al (2013) Human embryonic stem cell-derived test systems for developmental neurotoxicity: a transcriptomics approach. Arch Toxicol 87(1):123-143. https://doi. org/10.1007/s00204-012-0967-3

Lee WK, Probst S, Santoyo-Sánchez MP (2017) Initial autophagic protection switches to disruption of autophagic flux by lysosomal instability during cadmium stress accrual in renal NRK-52E cells. Arch Toxicol 91(10):3225-3245

Leist M, Ghallab A, Graepel R (2017) Adverse outcome pathways: opportunities, limitations and open questions. Arch Toxicol 91(11):3477-3505. https://doi.org/10.1007/s00204-017-2045-3 (Review)

Reffatto V, Rasinger JD, Carroll TS (2018) Parallel in vivo and in vitro transcriptomics analysis reveals calcium and zinc signalling in the brain as sensitive targets of HBCD neurotoxicity. Arch Toxicol 92(3):1189-1203

Reif R, Karlsson J, Günther G (2015) Bile canalicular dynamics in hepatocyte sandwich cultures. Arch Toxicol 89(10):1861-1870. https://doi.org/10.1007/s00204-015-1575-9

Rempel E, Hoelting L, Waldmann T (2015) A transcriptome-based classifier to identify developmental toxicants by stem cell testing: design, validation and optimization for histone deacetylase inhibitors. Arch Toxicol 89(9):1599-1618. https://doi.org/10.1007/ s00204-015-1573-y

Sachinidis A, Albrecht W, Nell P (2019) Road map for development of stem cell-based alternative test methods. TRMOME. https:// doi.org/10.1016/j.molmed.2019.04.003 (Published 23 May 2019)

Shinde V, Hoelting L, Srinivasan SP (2017) Definition of transcriptome-based indices for quantitative characterization of chemically disturbed stem cell development: introduction of the STOP-Toxukn and STOP-Toxukk tests. Arch Toxicol 91(2):839-864. https ://doi.org/10.1007/s00204-016-1741-8

Sisnaiske J, Hausherr V, Krug AK (2014) Acrylamide alters neurotransmitter induced calcium responses in murine ESC-derived and primary neurons. Neurotoxicology 43:117-126. https://doi. org/10.1016/j.neuro.2014.03.010

Sjögren AK, Breitholtz K, Ahlberg E et al (2018) A novel multi-parametric high content screening assay in ciPTEC-OAT1 to predict drug-induced nephrotoxicity during drug discovery. Arch Toxicol 92(10):3175-3190. https://doi.org/10.1007/s00204-018-2284-y

Vartak N, Damle-Vartak A, Richter B et al (2016) Cholestasis-induced adaptive remodeling of interlobular bile ducts. Hepatology 63(3):951-964. https://doi.org/10.1002/hep.28373

Waldmann T, Rempel E, Balmer, (2014) Design principles of concentration-dependent transcriptome deviations in drug-exposed differentiating stem cells. Chem Res Toxicol 27:3 (S. 408-420. - ISSN 0893-228X. - eISSN 1520-5010)

Yang B, Bai Y, Yin C (2018) Activation of autophagic flux and the Nrf2/ARE signaling pathway by hydrogen sulfide protects against acrylonitrile-induced neurotoxicity in primary rat astrocytes. Arch Toxicol 92(6):2093-2108

Publisher's Note Springer Nature remains neutral with regard to jurisdictional claims in published maps and institutional affiliations. 